\title{
MODEL MENTAL MAHASIWA BARU DALAM MEMAHAMI KONSEP STRUKTUR ATOM DITINJAU DARI PENGETAHUAN AWAL
}

\author{
Sunyono ${ }^{1)}$ \\ Leny Yuanita ${ }^{2)}$ \\ Muslimin Ibrahim ${ }^{3)}$ \\ ${ }^{1)}$ Prodi Pendidikan Kimia FKIP Universitas Lampung \\ ${ }^{2)}$ Program Studi Pendidikan Sains Pascasarjana Universitas Negeri Surabaya \\ ${ }^{3)}$ Program Studi Pendidikan Sains Pascasarjana Universitas Negeri Surabaya \\ e-mail: sunyono_ms@yahoo.com
}

\begin{abstract}
Several studies have shown that mental models can affect a student's ability to perform reasoning on external representation faced. Student mental models are generally used to thinking in order to solve the problem. This study aims to look at the characteristics of mental models beginning of students in understand the concept of atomic structure. Samples were taken at random from the students of Department of Mathematics and Natural Sciences, class of 2012 with the grouping based on students' prior knowledge. The number of samples involved as many as 72 people consisting of students with the prior knowledge of high, medium, and low. Diagnostic tests are used to see the essays shaped the emergence of mental models. The results showed that for all groups of prior knowledge, mental models beginning of students in understand the concept of atomic structure is still dominated by verbal mental model with the category of "very bad" and "bad" or the characteristics of mental model "formless/not clear" and mental model "intermediates_1." These results imply that the mental models of students can be used as a reference in setting learning to help students in solving problems related to the three levels of chemical phenomenon. To build a mental models of students towards a better, should be designed study involving interconnected between the third-levels of chemical phenomenon (macro, submicro, and symbolic).
\end{abstract}

Keywords: mental models, prior knowledge; atomic structure.

\section{PENDAHULUAN}

Pembelajaran kimia pada dasarnya mencakup tiga jenis representasi kimia, yaitu makro, submikro, dan simbolik. Penelitian secara konsisten menunjukkan bahwa siswa mengalami kesulitan dalam memahami dan menafsirkan representasi (terutama submikro) dalam membuat terjemahan di antara ketiga jenis representasi tersebut dan dalam membangun kemampuan representasional mereka (Johnstone, 1993; Treagust, et al., 2003; Chittleborough, and Treagust, 2007; Gkitzia, et al., 2011). Oleh sebab itu, dalam membangun pengetahuan konseptual yang lebih mendalam hendaknya pembelajaran kimia dilakukan dengan melibatkan ketiga jenis representasi tersebut. Pada kenyataannya, pembelajaran kimia yang berlangsung selama ini cenderung memprioritaskan hanya pada jenis representasi makroskopik dan simbolik secara verbal (Chittleborough and Treagust, 2007; Liliasari, 2007; Sunyono, dkk., 2011). Dalam pembelajaran, representasi submikroskopik umumnya hanya di represensikan secara verbal, dan model-model molekul kurang mendapatkan apresiasi, padahal model-model molekul tersebut dapat menjembatani pembelajaran kimia di antara ketiga jenis representasi kimia (makro, submikro, dan simbolis).

Penelitian yang telah dilakukan oleh Tasker dan Dalton (2006) menunjukkan bahwa penggunaan model konkrit, representasi gambar, animasi dan simulasi telah terbukti menguntungkan bagi proses pemahaman konsep kimia pembelajar khususnya pada konsep level molekul atau submikroskopik. Menurut Tasker dan Dalton (2006) bahwa "Chemistry involves interpreting observable changes in matter (eg. colour changes, smells, bubbles) at the concrete macroscopic or laboratory level and in terms of imperceptible changes in structure and processes at the imaginary sub-micro or molecular level." Ilmu kimia selalu melibatkan proses-proses perubahan yang dapat diamati (misalnya perubahan warna, bau, gelembung) di tingkat makroskopik atau laboratorium, dan perubahan yang tidak dapat diamati dengan indera mata, seperti perubahan struktur atau proses di tingkat sub-mikro atau molekul imajiner. Perubahan-perubahan di tingkat molekuler ini kemudian digambarkan pada tingkat simbolik yang abstrak dalam dua cara, yaitu secara kualitatif: menggunakan notasi khusus, bahasa, diagram, dan simbolisme, dan secara kuantitatif dengan menggunakan matematika (persamaan dan grafik).

Pernyataan Tasker \& Dalton (2006) tersebut berkaitan dengan transformasi representasi eksternal ke dalam representasi internal (yang selanjutnya diekspresikan sebagai model mental). Pakar psikologi kognitif Johnson-Laird (dalam Solaz-Portolẻs and Lopez, 2007) merumuskan suatu definisi model mental dalam 
upayanya untuk menjelaskan proses-proses penalaran seseorang dalam mengerjakan tugas silogisme dan membentuk representasi internal berupa model mental dalam suatu working memory (memori kerja = MK) tentang dunia dan mengkombinasikan informasi yang telah tersimpan dalam memori jangka panjang dengan informasi yang ada pada karakteristik dari tugas tersebut, kemudian diekstrak oleh proses-proses perseptual dalam memori. Senge (2004) mendefinisikan model mental sebagai berikut "Mental models are deeply held internal images of how the world works, images that limit us to familiar ways of thinking and acting. Very often, we are not consciously aware of our mental models or the effects they have on our behavior. " Definisi dari Senge tersebut dapat diartikan bahwa model mental merupakan image (gambaran) internal yang dipegang teguh tentang bagaimana dunia bekerja, gambaran yang membatasi kita untuk berpikir dan bertindak. Sering terjadi, kita tidak menyadari adanya model mental atau pengaruhnya terhadap perilaku kita.

Beberapa penelitian tentang model mental telah menemukan bahwa banyak siswa memiliki model mental yang sangat sederhana tentang fenomena kimia, misalnya model-model atom dan model-model molekul yang digambarkan sebagai struktur diskrit dan konkrit, namun tidak memiliki keterampilan membangun model mental yang lebih komplek (Chittleborough and Treagust, 2007; Coll, 2008; Guzel \& Adadan, 2013). Guzel \& Adadan (2013) memanfaatkan beberapa representasi dalam pembelajaran untuk mengembangkan pemahaman kimia mahasiswa calon guru tentang struktur materi. Hasilnya, meskipun mahasiswa telah mampu mengembangkan kemampuan representasional, namun gambar struktur yang dibuat masih sangat sederhana. Coll (2008) melaporkan dalam penelitiannya tentang "mental models of chemical bonding" bahwa baik siswa sekolah menengah, sarjana, maupun pascasarjana lebih suka dengan model mental yang sederhana dan realistis. Chittleborough and Treagust (2007) dalam penelitiannya melaporkan bahwa model mental pembelajar dapat terbentuk melalui interpretasi, pemahaman, dan penjelasan terhadap fenomena representasi submikro, namun kebanyakan pembelajar lebih suka menggunakan model mentalnya pada fenomena representasi yang sederhana. Salah satu caranya adalah dengan menggunakan visualisasi yang cocok untuk suatu topik pembelajaran. Studi yang dilakukan Sunyono, dkk (2011) melaporkan bahwa model mental mahasiswa masih cenderung berada pada level makroskopis dan simbolis, level submikroskopisnya masih belum terbangun dengan baik. Ini disebabkan mahasiswa mengalami kesulitan dalam membuat interpretasi terhadap fenomena sumikro.

Merujuk pada hasil penelitian Sunyono, dkk (2009), pembelajaran topik struktur atom hendaknya dilakukan dengan melibatkan representasi submikroskopis, karena karakteristiknya yang bersifat abstrak dan teori atom atau sifat materi merupakan konsep utama dalam ilmu pengetahuan dan teknologi (Gkitzia, et al., 2011). Park, et al (2009) menyatakan bahwa teori tentang atom adalah konsep yang utama dalam pembelajaran sains dan konsep-konsepnya bersifat abstrak, sehingga cara mengajar dan belajar tentang teori atom perlu diperhatikan dengan baik, terutama dalam memilih strategi dengan memanfaatkan visualisasi. Wang (2007) dalam disertasinya melaporkan bahwa pembelajaran tentang struktur atom, terutama kedudukan elektron dalam atom memerlukan model visualisasi yang dirancang sedemikian rupa, sehingga dapat membantu mahasiswa dalam melakukan interpretasi terhadap fenomena elektron dalam atom dan model mental mahasiswa dapat terbangun dengan baik. Hilton \& Nichols (2011) melaporkan bahwa pemahaman terhadap fenomena yang lebih kompleks dan abstrak seperti topik struktur atom, tidak dapat dicapai oleh pembelajar tanpa melibatkan representasi submikroskopik dan simbolik. Demikian pula, penelitian yang dilakukan oleh Guzel \& Adadan (2013) melaporkan bahwa pembelajaran yang dirancang dengan mengembangkan pemahaman terhadap berbagai representasi (fenomena makro, submikro, dan simbolis) dapat menghasilkan pemahaman representasional yang lebih mendalam tentang struktur materi dan dapat dipertahankan hingga 17 bulan lamanya.

Para peneliti mempelajari model mental seseorang dengan mengelompokkan ke dalam beberapa karakteristik, seperti: Norman (dalam Barsalou, 1992) membagi karakteristik model mental menjadi 2 bagian, yaitu model mental struktural dan model mental konseptual. Pada penelitian bidang pendidikan, umumnya para peneliti mempelajari model mental dengan memfokuskan pada model konseptual. Terkait dengan penelitian model mental dalam pendidikan, Wang (2007) dan Jaber \& Boujaoude (2012) mengklasifikasi karakteristik model mental (konseptual) ke dalam tiga kategori berdasarkan skor perolehan jawaban mahasiswa terhadap pertanyaan dalam tes model mental, yaitu: model mental "tinggi" (jawaban mahasiswa mencapai $\geq$ $70 \%$ benar), model mental "moderat" (jika 50\% > jawaban mahasiswa benar $<70 \%$ ), dan model mental "rendah" (jawaban mahasiswa yang benar $\leq 50 \%$ ). Sedangkan Park, et al (2009) mengklasifikasi karakteristik model mental ke dalam 5 bagian, yaitu (1) 
model mental awal yang tidak berbentuk atau tidak jelas adalah model mental yang sudah dibawa oleh seseorang sejak lahir dan muncul akibat informasi dari lingkungan yang salah atau konsep/penjelasan dan gambar struktur yang dibuat sama sekali tidak dapat diterima secara keilmuan atau pembelajar sama sekali tidak memiliki konsep; (2 ) model mental intermediet 1 adalah model mental yang sudah mulai terbentuk dan ditandai dengan konsep/penjelasan yang diberikan mendekati kebenaran keilmuan dan gambar struktur yang dibuat tidak dapat diterima atau sebaliknya; (3) model mental intermediet 2 adalah model mental pembelajar yang ditandai dengan konsep/penjelasan yang dimiliki pembelajar benar sebagian dan gambar struktur yang dibuat mendekati kebenaran keilmuan; (4) model mental intermediet 3 merupakan model mental yang dapat dikategorikan sebagai model mental konsensus, yaitu ditandai dengan konsep/penjelasan yang dimiliki pembelajar dapat diterima secara keilmuan dan gambar struktur yang dibuat mendekati kebenaran atau sebaliknya penjelasan/konsep yang dimiliki belum dapat diterima dengan baik secara keilmuan, tetapi gambar struktur yang dibuat tepat; dan (5) model mental target adalah model mental yang ditandai dengan konsep/penjelasan dan gambar struktur yang dibuat pembelajar tepat secara keilmuan. Penelitian ini dilakukan untuk menjawab pertanyaan: "bagaimana karakteristik model mental mahasiswa baru dalam memahami konsep struktur atom?"

\section{METODE PENELITIAN}

\section{Desain Penelitian dan Sampel Penelitian}

Penelitian ini merupakan jenis penelitian kualitatif, sehingga dalam pelaksanaanya tidak memerlukan pengontrolan terhadap perlakuan. Fokus dalam penelitian adalah model mental mahasiswa baru dalam memahami struktur atom yang selanjutnya disebut sebagai model mental awal. Sampel dalam penelitian dipilih secara acak dengan teknik stratified random sampling dari mahasiswa Jurusan PMIPA angkatan 2012. Sampel diambil dengan cara dikelompokkan berdasarkan pengetahuan awal kimia mahasiswa melalui pretes terhadap tingkat penguasaan konsep struktur atom. Soal pretes untuk pengelompokan ini di ambil dari bank soal UN dan tes masuk perguruan tinggi berbentuk tes objektif 5 opsi. Berdasarkan hasil tes pengetahuan awal tersebut, mahasiswa di kelompokkan ke dalam kelompok berpengetahuan awal tinggi, sedang, dan rendah. Selanjutnya masing-masing program studi dan kelompok diambil 6 orang mahasiswa, sehingga total sampel penelitian berjumlah 72 orang yang kemudian dijadikan 2 kelas. Hasil pemilihan sampel mahasiswa secara rinci dicantumkan dalam Tabel 1 berikut.

\begin{tabular}{|l|l|c|c|c|c|}
\hline \multicolumn{1}{c|}{$\begin{array}{c}\text { Program } \\
\text { Studi }\end{array}$} & \multicolumn{3}{|c|}{$\begin{array}{c}\text { Pengetahuan Awal } \\
\text { Mahasiswa }\end{array}$} & Jumlah \\
\cline { 2 - 6 } & Tinggi & Sedang & Rendah & \\
\hline $\begin{array}{l}\text { Pendidikan } \\
\text { Matematika }\end{array}$ & 6 & 6 & 6 & 18 \\
\hline $\begin{array}{l}\text { Pendidikan } \\
\text { Fisika }\end{array}$ & 6 & 6 & 6 & 18 \\
\hline $\begin{array}{l}\text { Pendidikan } \\
\text { Kimia }\end{array}$ & 6 & 6 & 6 & 18 \\
\cline { 2 - 6 } Tabel & $\begin{array}{l}\text { Pendidikan } \\
\text { Biologi }\end{array}$ & 6 & 6 & 6 & 18 \\
\cline { 2 - 6 } & Jumlah & 24 & 24 & 24 & $\mathbf{7 2}$ \\
\hline
\end{tabular}

. Jumlah Mahasiswa sebagai Sampel Penelitian

\section{Instrumen dan Analisis Data}

Model mental awal mahasiswa yang diukur dalam penelitian ini adalah model mental konseptual yang muncul sebagai respon terhadap pertanyaan-pertanyaan dalam soal tes diagnostik pada topik struktur atom (terutama model atom Rutherford, Bohr, dan mekanika gelombang). Instrumen yang digunakan untuk mengetahui kemunculan model mental awal mahasiswa tersebut adalah berbentuk tes diagnostik model mental atau disebut tes model struktur atom (TMS). Instrumen tes diadaptasi dari model yang dikembangkan oleh Wang (2007) dan Park \& Light (2009), yaitu berupa tes tertulis berbentuk essay yang dilengkapi dengan gambar submikro. Jumlah soal diagnostik dalam penelitian ini sebanyak 4 item tes. Selanjutnya dilakukan wawancara terhadap 3 (tiga) orang mahasiswa yang terpilih yang mewakili masing-masing kelompok pengetahuan awal. Wawancara terhadap mahasiswa ini dilakukan untuk mengetahui lebih mendalam tentang jawaban mahasiswa dan kesulitan-kesulitan yang muncul dalam menyelesaikan masalah.

Data yang diperoleh dari hasil tes diagnostik dan wawancara tersebut selanjutnya dianalisis dengan cara ditranskripsi dan dikategorisasi, sehingga dapat diidentifikasi model mental awal mahasiswa dan kesulitan-kesulitan yang umum terjadi ketika berhadapan dengan repesentasi eksternal level submikroskopik, terutama dalam menyelesaikan masalah tentang konsep model atom. Untuk mengkategorisasi kemunculan model mental, terhadap jawaban mahasiswa atas soal tes diagnostik dilakukan dengan sistem penskoran. Teknik penskoran dilakukan dengan menggunakan rubrik, yaitu dengan cara menilai jawaban mahasiswa atas soal tes dengan uraian menggunakan label untuk menentukan tingkat pencapaian penyelesaian masalah. Tingkat pencapaian penyelesaian masalah tersebut selanjutnya di 
dikategorikan sebagai model mental "buruk sekali" (bila skor =1), "buruk" (skor = 2), "sedang"atau "moderat" $($ skor $=3)$, "baik" (skor $=4)$, dan "baik sekali" ( Berdasarkan hasil penskoran dan kategorisasi tersebut, selanjutnya model mental mahasiswa yang muncul dikarakterisasi ke dalam 5 karakter model mental (Park, et al., 2009), yaitu model yang tidak jelas, intermediet 1 , intermediet 2 , intermediet 3 , dan target.

\section{HASIL PENELITIAN DAN PEMBAHASAN}

Pertanyaan pada tes diagnostik untuk melihat kemunculan model mental awal mahasiswa dalam memahami topik struktur atom meliputi 4 pertanyaan tentang model atom inti (Rutherford), model atom Bohr, dan model mekanika gelombang. Pertanyaan yang diajukan mencakup interpretasi terhadap fenomena submikro melalui penjelasan verbal, gambar visual, dan simbolik. Hasil penelitian menunjukkan bahwa mahasiswa dengan pengetahuan awal tinggi, sedang, dan rendah memiliki kemampuan model mental yang sama, yaitu berada pada kategori "buruk" dan "buruk sekali." Hasil analisis kemunculan model mental awal mahasiswa sebagai respon terhadap pertanyaan tes diagnostik model struktur atom (TMS) dicantumkan pada Gambar 1 berikut.

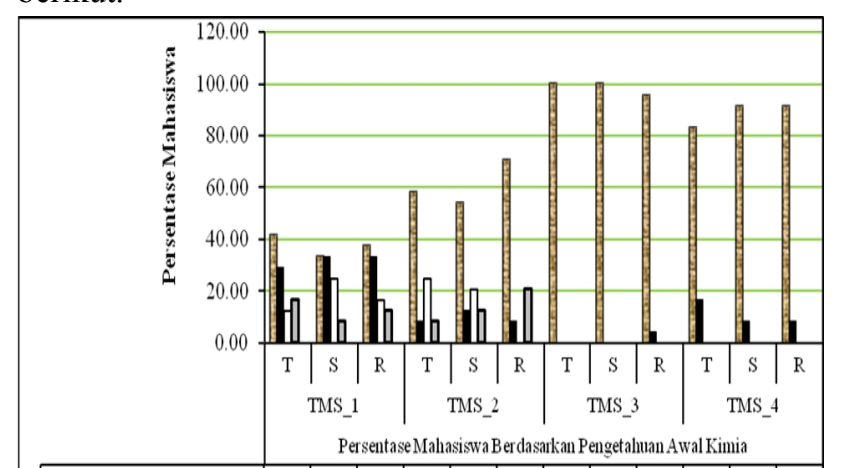

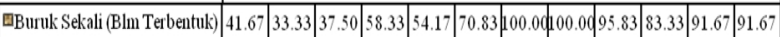

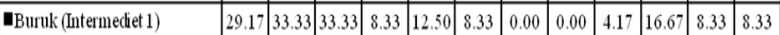
\begin{tabular}{|l|l|l|l|l|l|l|l|l|l|l|l|l|}
\hline QSedang (Intermediet 2) & 12.50 & 25.00 & 16.67 & 25.00 & 20.83 & 0.00 & 0.00 & 0.00 & 0.00 & 0.00 & 0.00 & 0.00
\end{tabular} \begin{tabular}{|l|l|l|l|l|l|l|l|l|l|l|l|l|}
\hline DBaik (Intermediet 3) & 16.67 & 8.33 & 12.50 & 8.33 & 12.50 & 20.83 & 0.00 & 0.00 & 0.00 & 0.00 & 0.00 & 0.00 \\
\hline
\end{tabular}

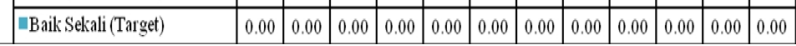
Keterangan: Pengetahuan Awal $\mathrm{T}=$ Tinggi; $\mathrm{S}=$ Sedang; dan $\mathrm{R}=$ Rendah

Gambar 1 Persentase Mahasiswa dengan Model Mental Awal pada Karakteristik Tertentu untuk Tiap Item Tes

Berdasarkan jawaban mahasiswa atas pertanyaan TMS_1 dapat dikatakan bahwa mahasiswa dengan pengetahuan awal tinggi, sedang, dan rendah memberikan respon yang tidak berbeda, sehingga menghasilkan model mental awal yang sama, yaitu "buruk" dan "buruk sekali." Mahasiswa dengan modal pengetahuan kimia dari sekolah menengah (SMA) masih belum mampu melakukan transformasi dari makroskopik (fenomena percobaan Thomson, Goldstein, Chadwick, dan Rutherford) ke fenomena submikroskopik dan simbolik, yaitu dengan melakukan imajinasi terhadap susunan partikel dalam atom kemudian menyusun gambar submikro tentang bagian-bagian dari atom dan menuliskan secara simbolik susunan elektron, proton, dan netron dalam suatu atom berdasarkan gambar visual. Gambar visual yang dibuat mahasiswa masih sangat sederhana dan sebagian besar $(41,67 \%)$ nampak tidak dapat membedakan antara model atom Rutherford dan model atom Bohr. Kesulitan mahasiswa dapat disebabkan karena mahasiswa tidak biasa dilibatkan dengan fenomena sub-mikroskopik dalam pembelajaran. Hasil ini nampaknya sesuai dengan pernyataan beberapa peneliti bahwa pemahaman terhadap konsep kimia tidak saja pemahaman terhadap algoritmanya saja atau hapalan secara verbal saja, tetapi juga menuntut pemahaman terhadap fenomena representasi submikroskopik dari struktur molekul atau atom (Ben-Zvi, et al., 1987; Coll and Treagust, 2003; Davidowitz, et al., 2010). Penelitian lain, seperti Coll (2008) menyatakan bahwa kemampuan peserta didik untuk mengoperasikan atau menggunakan model mental mereka dalam rangka menjelaskan peristiwa-peristiwa yang melibatkan penggunaan representasi submikro sangat terbatas, sehingga perlu adanya latihan dalam menginterpretasikan gambar visual submikro melalui pembelajaran yang melibatkan 3 level fenomena kimia. Selanjutnya Devetak, et al. (2009) menemukan bahwa mahasiswa yang belum di latih dengan representasi eksternal akan mengalami kesulitan dalam menginterpretasikan struktur submikro dari suatu molekul atau atom.

Analisis terhadap jawaban mahasiswa terhadap pertanyaan TMS_2 menunjukkan hasil yang sama dengan hasil analisis TMS 1. Untuk semua pengetahuan awal (tinggi, sedang, dan rendah) mayoritas mahasiswa $(>66,00 \%)$ memiliki model mental awal dalam memahami model orbit Bohr berada pada kategori "buruk" dan "buruk sekali," atau dengan karakteristik model mental "yang tidak berbentuk/tidak jelas" dan "intermediet 1. Hasil ini menunjukkan bahwa dengan modal pengetahuan awal yang diperoleh dari bangku sekolah menengah, mahasiswa masih mengalami kesulitan dalam membuat transformasi fenomena verbal ke visual tentang model atom Bohr. Kesulitan tersebut disebabkan mahasiswa tidak melakukan imajinasi dengan baik akibat belum dilatihnya dalam melakukan imajinasi representasi terhadap fenomena submikro tentang struktur atom model Bohr. 
Hasil analisis terhadap jawaban mahasiswa atas pertanyaan TMS_2 menunjukkan bahwa sebagian mahasiswa dengan pengetahuan awal tinggi dan sedang (25,00\% dan 20,83\%) sebenarnya mampu melakukan interpretasi dan membuat transformasi terhadap fenomena yang diberikan, namun ada kesalahan pemahaman dalam menggambarkan model atom flour dan natrium. Jawaban mahasiswa terinterferensi dengan model mekanika gelombang, yaitu dengan membuat konfigurasi elektron menggunakan orbital $\mathrm{s}$ dan $\mathrm{p}$, padahal yang ditanyakan adalah model Bohr yang belum mengenal istilah orbital. Akibat adanya kesalahan interpretasi tersebut jawaban mahasiswa atas soal TMS_2 menghasilkan model mental awal dengan kategori "buruk" dan "buruk sekali." Hasil wawancara mengindikasikan bahwa kemampuan melakukan interpretasi tersebut dalam membedakan model Bohr dan model mekanika gelombang memang tidak dilatihkan dalam pembelajaran sewaktu mereka duduk dibangku sekolah menengah. Hal ini sejalan dengan hasil penelitian Wang \& Barrow (2013) bahwa pembelajaran yang tidak melibatkan integrasi antara representasi submikro dan simbolik menyebabkan mahasiswa mengalami kesulitan dalam menggambarkan dan menjelaskan model atom Bohr secara rinci (dan tepat).

Terhadap pertanyaan TMS_3 dan TMS_4 juga menunjukkan hal yang sama, di mana dengan pengetahuan awal kimia mahasiswa yang diperoleh sewaktu duduk di sekolah menengah masih belum mampu membangun model mental awal dengan baik. Mayoritas mahasiswa ( $>95,00 \%)$ memiliki kemampuan yang sangat rendah dalam menyelesaikan masalah tentang konfigurasi elektron model Bohr dan model mekanika gelombang, sehingga menghasilkan model mental awal yang berada pada kategori "buruk" dan "buruk sekali," atau dengan karakteristik model mental "yang tidak berbentuk/tidak jelas" dan "intermediet 1."

Pertanyaan TMS_3 merupakan pertanyaan yang terkait dengan pernyataan visual, dimana mahasiswa diminta untuk membuat transformasi dari verbal ke visual (submikro) dan simbolik atau sebaliknya tentang penentuan orbit elektron menurut Bohr kemudian membuat gambaran visual melalui diagram tingkat energi. Untuk semua pengetahuan awal mahasiswa menunjukkan bahwa mayoritas $(>95,00 \%)$ mengalami kesulitan dalam membuat transformasi yang diminta. Mahasiswa tidak mampu memberikan gambar orbit elektron yang sesuai dengan model Bohr dan diagram tingkat energi dengan baik. Analisis terhadap jawaban mahasiswa atas pertanyaan TMS_3 memberikan informasi bahwa baik mahasiswa dengan pengetahuan awal tinggi, sedang, dan rendah, sama-sama belum mampu melakukan interpretasi terhadap energi elektron pada tingkat tertentu dan energi transisinya, serta belum mampu memberikan penjelasan bagaimana dengan energi kinetik dan energi potensial dari elektron dalam atom hidrogen pada orbit $\mathrm{n}=1$ dan $\mathrm{n}=3$. Mahasiswa juga belum mampu membuat interpretasi terhadap energi kinetik dan energi potensial dari elektron dalam atom hidrogen yang didasarkan pada logika matematik melalui perhitungan energi pada $n=1$ dan $n=$ 3 , serta energi transisi ketika elektron melompat dari orbit $\mathrm{n}=3 \mathrm{ke} \mathrm{n}=1$.

Hasil yang sama juga terjadi pada jawaban mahasiswa terhadap pertanyaan TMS_4. Pertanyaan pada TMS_4 merupakan pertanyaan yang terkait dengan hubungan antara tingkat energi dan konfigurasi elektron berdasarkan orbitalnya, di mana mahasiswa diminta untuk membuat transformasi dari verbal (makro) ke visual (submikro) dan simbolik atau sebaliknya tentang konfigurasi elektron berdasarkan diagram tingkat energi dari suatu atom dan keempat bilangan kuantumnya, kemudian membuat gambaran visual tentang diagram tingkat energi dari setiap orbital yang terisi oleh elektron. Pada jawaban mahasiswa nampak bahwa mahasiswa belum memiliki kemampuan dalam menentukan dan memberikan penjelasan tentang tingkat energi dari elektron pada orbital-orbital dari atom flour. Kesulitan dalam menentukan tingkat energi merupakan faktor penyebab mahasiswa tidak dapat membuat gambar visual tentang diagram tingkat energi dan menentukan keempat bilangan kunatum dari elektron atom flour dengan tepat. Dalam hal ini, mahasiswa lebih banyak menggunakan istilah-istilah kulit elektron yang merupakan konsep model atom Bohr bukan konsep mekanika gelombang. Mahasiswa terinterferensi dengan konsep model Bohr, padahal pada konsep mekanika gelombang istilah kulit elektron sebaiknya dihindari, karena kedudukan elektron tidak dapat ditentukan secara pasti, sehingga akan lebih sesuai bila digunakan istilah tingkat energi dan orbital.

Berdasarkan hasil wawancara menunjukkan bahwa mahasiswa kesulitan dalam membedakan model atom Bohr dan model mekanika gelombang, karena menurut mahasiswa, model atom mekanika gelombang tidak dipelajari secara detail ketika mereka belajar di sekolah menengah. Hasil wawancara juga memberikan informasi bahwa kesulitan-kesulitan yang dihadapai mahasiswa disebabkan sewaktu mereka duduk dibangku sekolah menengah tidak mendapatkan pengalaman dalam melakukan interpretasi terhadap orbit elektron menurut Bohr dan energi yang menyertai pergerakan elektron tersebut, serta bagaimana model mekanika gelombang 
dalam memberikan penjelasan tentang kedudukan dan perilaku elektron di dalam atom.

Hasil-hasil analisis tersebut di atas, nampaknya sejalan dengan temuan Park \& Light (2009) bahwa kesulitan mahasiswa dalam memahami konsep-konsep yang bersifat abstrak dapat disebabkan oleh pengalaman sehari-hari yang tidak mendukung dalam menyelesaikan masalah yang melibatkan fenomena representasi submikro. Selanjutnya menurut Park, et al (2009), teori tentang atom adalah konsep utama dalam sains, sehingga cara mengajar dan cara belajar tentang teori atom melalui model-model atom perlu diperhatikan dengan baik dalam memilih strategi yang mampu meningkatkan kemampuan model mental mahasiswa dari model "inetrmediet 1 " dengan kategori "buruk" ke model mental "intermediet 3" dan "target" dengan kategori "baik" dan "baik sekali." Wang \& Barrow (2013) melaporkan bahwa mahasiswa dengan skor model mental moderat (sedang) dan rendah sangat sulit dalam membuat visualisasi fenomena elektron dalam atom dan transisi energinya. Wang (2007) dalam disertasinya melaporkan bahwa mahasiswa dengan skor model mental tinggi, sedang, dan rendah sama-sama memiliki kesulitan dalam hal visualisasi elektron dalam atom. Demikian pula, Hilton \& Nichols (2011) melaporkan bahwa pemahaman terhadap fenomena yang lebih kompleks dan abstrak tidak dapat dicapai tanpa penggunaan berbagai representasi, terutama integrasi antara representasi level submikroskopik dan simbolik. Berdasarkan temuan ini dan dukungan penelitian sebelumnya menunjukkan bahwa pembelajaran yang tidak memberikan pengalaman dan latihan kepada mahasiswa dalam melakukan interpretasi, penjelasan konseptual, dan transformasi di antara ketiga level fenomena kimia akan menghasilkan penyelesaian masalah kimia yang rendah, sehingga sulit membangun model mental dengan kategori "baik" dan "baik sekali."

Implikasi dari penelitian ini adalah analisis terhadap model mental awal dapat dijadikan sebagai dasar dalam menetapkan strategi pembelajaran kimia dasar. Salah satu strategi pembelajaran yang dapat digunakan dalam membangun model mental adalah pembelajaran dengan melibatkan tiga jenis representasi kimia (fenomena makro, submikro, dan simbolik). Tujuannya agar mahasiswa mampu memberikan eksplanasi dan memperoleh pengetahuan konseptual yang mendalam, sehingga mahasiswa dapat lebih mudah dalam menyelesaikan masalah-masalah kimia yang terkait dengan konsep-konsep abstrak. Studi tentang model mental awal ini sangat diperlukan sebagai pijakan dalam menentukan strategi pembelajaran. Mengingat model mental merupakan suatu representasi internal yang dipakai oleh seseorang untuk berpikir dan dengan demikian mempengaruhi perkembangan kognitif pembelajar (Chittleborough, and Treagust, 2007; Tasker \& Dalton, 2006; Senge, 2004; Ben-Zvi, et al., 1987).

\section{SIMPULAN}

1. Model mental awal mahasiswa dalam memahami konsep struktur atom masih didominasi oleh model mental yang bersifat verbal dengan kategori "buruk sekali" dan "buruk" atau dengan karakteristik model mental "yang tidak jelas" dan model mental "intermediet 1," baik untuk mahasiswa dengan pengetahuan awal kimia tinggi, sedang, dan rendah.

2. Kesulitan-kesulitan mahasiswa dalam menginterpretasikan fenomena kimia antara lain:

a. mengidentifikasi representasi eksternal (verbal dan visual) tentang kedudukan elektron, proton, dan netron dalam atom sesuai dengan masing-masing model atom (model partikel, model inti, dan mekanika gelombang)..

b. mentransformasi representasi submikro (visual) ke verbal dan simbolik atau sebaliknya.

c. belum terlatih dalam melakukan imajinasi terhadap fenomena representasi submikro.

\section{SARAN / REKOMENDASI}

1. Model mental awal hasil penelitian ini merupakan gambaran awal kemampuan mahasiswa dalam berpikir tentang konsep struktur atom. Informasi tentang model mental awal dapat dijadikan pijakan dalam menentukan strategi pembelajaran kimia dasar untuk membangun pemahaman konsep yang bermakna. Membangun pemahaman konsep yang bermakna memerlukan pengembangan model mental dan pengemasan pembelajaran untuk menghasilkan keterampilan penalaran yang sistematis.

2. Model pembelajaran yang dapat mengembangkan model mental mahasiswa ke arah model mental "baik" dan "baik sekali" adalah model pembelajaran yang dikemas dengan melibatkan tiga level fenomena kimia (makro, submikro, dan simbolik) melalui strategi kooperatif dan imajinatif. 


\section{DAFTAR PUSTAKA}

Barsalou, L.W. (1992). "Cognitive Psychology: An Overview for Cognitive Scientist," LEA (Lawrence Erlbaum Associates), Inc.Publisher. Hillsdale., New Jersey. 410 page.

Ben-Zvi, R., Eylon B. and Silberstein, J. (1987). "Students' Visualisation of A Chemical Reaction," Educ. Chem., 24, 117-120.

Chittleborough, G.D. and Treagust D. F. (2007). "The Modelling Ability Of Non-Major Chemistry Students And Their Understanding Of The Sub-Microscopic Level," Chem. Educ. Res. Pract., 8, 274-292.

Coll, R.K. (2008). "Chemistry Learners' Preferred Mental Models for Chemical Bonding," Journal of Turkish Science Education, 5, (1), p. 22 - 47.

Coll, R.K. and Treagust, D.F. (2003). "Investigation of Secondary School, Undergraduate and Graduate Learners' Mental Models of Ionic Bonding," Journal of Research in Science Teaching, 40, p. $464-486$.

Davidowitz, B., Chittleborough, G.D., and Eileen, M. (2010). "Student-Generated Submicro Diagrams: A Useful Tool for Teaching and Learning Chemical Equations and Stoichiometry. Chem. Educ. Res. Pract., 11, 154-164.

Devetak, I., Erna, D.L., Mojca, J., and Glažar, S.A. (2009). "Comparing Slovenian Year 8 and Year 9 Elementary School Pupils' Knowledge of Electrolyte Chemistry and Their Intrinsic Motivation. Chem. Educ. Res. Pract., 10, p. 281-290.

Gkitzia, V., Katerina S., and Chryssa T. (2011). "Development and Application of Suitable Criteria for the Evaluation of Chemical Representations in School Textbooks." Chem. Educ. Res. Pract., 12, p. 5-14.

Guzel, B.Y. \& Adadan, E. (2013). "Use of Multiple Representations in Developing Preservice Chemistry Teachers' Understanding of The Structure of Matter," International Journal of Environmental \& Science Education. 8, No. 1. p. 109-130.

Hilton, A. \& Nichols, K. (2011)."Representational Classroom Practices that Contribute to Students' Conceptual and Representational Understanding of Chemical Bonding," International Journal of Science Education. 33, No. 16. p. 2215-2246.

Johnstone, A. H. (1993). "The development of Chemistry Teaching: A Changing Response to Changing Demand". Journal of Chemical Education, 70. No. 9. p. 701-705.

Jaber, L.Z. and Boujaoude, S. (2012. "A Macro-MicroSymbolic Teaching to Promote Relational
Understanding of Chemical Reactions," International Journal of Science Education. 34, No. 7, p. 973-998.

Liliasari, (2007). "Scientific Concepts and Generic Science Skills Relationship In The 21 $1^{\text {st }}$ Century Science Education," dalam Proceeding of The First International Seminar of Science Education., 27 October 2007. Bandung. $13-18$.

Park, E.J. \& Light, G. (2009). "Identifying Atomic Structure as a Threshold Concept: Student Mental Models and Troublesomeness," International Journal of Science Education. 31, No. 2. p. 233258.

Park, E.J., Light, G., Swarat, S., \& Denise, D. (2009). "Understanding Learning Progression in Student Conceptualization of Atomic Structure by Variation Theory for Learing." dalam Paper presented at the Learning Progressions in Science (LeaPS) Conference, June 2009. Iowa City, IA.

Senge, P.M. (2004). "The Fifth Discipline. The Art and Practice of The Learning Organization." Doubleday Dell Publishing Group, Inc. New York. 405 page.

Solaz-Portolẻs, J.J., and Lopez, V.S. (2007). "Representations in Problem Solving in Science: Directions for Practice," dalam Asia-Pacific Forum on Science Learning and Teaching, 8, No. 2. Article 4.

Sunyono, Leny Y, \& Muslimin I. (2011). "Model Mental Mahasiswa Tahun Pertama dalam Mengenal Konsep Stoikiometri (Studi pendahuluan pada mahasiswa PS. Pendidikan Kimia FKIP Universitas Lampung," dalam Prosiding Seminar Nasional V. 6 Juli 2011. Universitas Islam Indonesia. Yogyakarta.

Sunyono, Wirya, I.W., Suyadi, G., dan Suyanto, E. (2009) "Pengembangan Model Pembelajaran Kimia Berorientasi Keterampilan Generik Sains pada Mahasiswa SMA di Propinsi Lampung," dalam Laporan Penelitian Hibah BersaingTahun I - Dikti, Jakarta.

Tasker, R. \& Dalton, R. (2006). "Research Into Practice: Visualization of The Molecular World Using Animations," Chem. Educ. Res.Prac.7, p.141-159.

Treagust, D. F., Chittleborough, G. D., \& Mamiala, T. (2003), "The Role of Submicroscopic and Symbolic Representations in Chemical Explanations," International Journal of Science Education., 25, No. 11, p. 1353-1368.

Wang, C.Y. (2007). "The Role of Mental-Modeling Ability, Content Knowlwdge, and Mental Models in General Chemistry Students' Understanding about 
Molecular Polari," Dissertation for the Doctor Degree of Philosophy in the Graduate School of the University of Missouri. Columbia.

Wang, C.Y. \& Barrow, L.H. (2013). “Exploring Conceptual Frameworks of Models of Atomic Structures and Periodic Variations, Chemical Bonding, and Molecular Shape and Polarity": A Comparison of Undergraduate General Chemistry Students with High and Low Levels of Content Knowledge. Chem. Educ. Res. Pract.,14. p. 130 146. 